\title{
Evidence of Zika Virus Infection in Pigs and Mosquitoes, Mexico
}

\author{
Daniel Nunez-Avellaneda, Rosa Carmina Cetina-Trejo, Emily Zamudio-Moreno, \\ Carlos Baak-Baak, Nohemi Cigarroa-Toledo, Guadalupe Reyes-Solis, Antonio Ortega-Pacheco, \\ Gerardo Suzán, Chandra Tandugu, Julián E. García-Rejón, Bradley J. Blitvich, Carlos Machain-Williams
}

Evidence suggests that pigs seroconvert after experimental exposure to Zika virus and are potential sentinels. We demonstrate that pigs are also susceptible to natural Zika virus infection, shown by the presence of antibodies in domestic pigs in Yucatan, Mexico. Zika virus RNA was detected in 5 species of mosquitoes collected inside pigpens.

P Digs are susceptible to experimental Zika virus infection (1-4), but evidence of natural infection is lacking. Microcephaly has occurred in fetal piglets after in utero inoculation, and neurologic disease has occurred in neonates after intracranial inoculation, suggesting that pigs are a suitable animal model for the study of Zika virus. Three-month-old pigs exposed to Zika virus through subcutaneous and intradermal injection produce antibodies but not viremias, indicating that pigs could be suitable sentinels. We performed a serologic investigation in the state of $\mathrm{Yu}-$ catan, Mexico, to determine whether pigs are susceptible to natural Zika virus infection. Mosquitoes temporally and spatially associated with the pigs were tested for evidence of Zika virus infection to increase our understanding of the vector range of the virus.

\section{The Study}

Pigs and mosquitoes were sampled at 4 sites. One site was a commercial farm in Xmatkuil, a suburb $16 \mathrm{~km}$ south of Merida, the largest city in Yucatan. The site contained a herd of Yucatan black hairless pigs and a commercial genetic line of breeding pigs. The other sites were Mayan villages to the east and southeast of

Author affiliations: Universidad Autonoma de Yucatan, Merida, Mexico (D. Nunez-Avellaneda, R. Carmina Cetina-Trejo,

E. Zamudio-Moreno, C. Baak-Baak, N. Cigarroa-Toledo,

G. Reyes-Solis, J.E. García-Rejón, C. Machain-Williams); lowa

State University, Ames, lowa, USA (D. Nunez-Avellaneda,

C. Tandugu, B.J. Blitvich); Universidad Autónoma de Yucatán,

Xmatkuil, Mexico; (A. Ortega-Pacheco); Universidad Nacional

Autónoma de México, Mexico City, Mexico (G. Suzán)

DOI: https://doi.org/10.3201/eid2702.201452
Merida: Tzucacab (148 km southeast), Valladolid (159 $\mathrm{km}$ east), and Xkalakdzonot (155 km southeast). Each village maintained herds of Yucatan black hairless pigs as a food source for residents. We visited each site 1-3 times during 2018 and 2019, and no pigs were sampled more than once. An unusually high number of porcine fetal deaths occurred in Xmatkuil and Xkalakdzonot several weeks before our initial visits. The stillborn pigs displayed signs of mummification but no apparent neurologic malformations, according to their owners. During each visit, we searched humanmade structures and vegetation for resting mosquitoes, which were collected by manual aspiration.

Serum samples were assayed by plaque-reduction neutralization test (PRNT) using dengue virus (DENV) serotype 1 (strain Hawaii), DENV serotype 2 (strain NGC), DENV serotype 3 (strain H-87), DENV serotype 4 (strain 241), Ilheus virus (original strain), St. Louis encephalitis virus (strain TBH-28), West Nile virus (strain NY99-35261-11), and Zika virus (strain PRVABC59). Serum specimens were initially screened at a dilution of 1:20 by using Zika virus. Positive samples were further diluted, then assayed using all 8 viruses. Titers were expressed as the reciprocal of serum dilutions yielding $\geq 90 \%$ reduction in the number of plaques ( $\mathrm{PRNT}_{90}$ ). For etiologic diagnosis, the $\mathrm{PRNT}_{90}$ antibody titer to the respective virus was required to be $\geq 4$-fold that of other flaviviruses tested.

Mosquitoes were transported alive to the arbovirus laboratory at the Universidad Autonoma de Yucatan and sorted into pools of $\leq 50$ according to species, sex, date, study site, and location within the study site. Mosquitoes were transported in RNAlater (Sigma-Aldrich, https://www.sigmaaldrich.com) to Iowa State University, then homogenized by using mortars and pestles. Total RNA was extracted by using Trizol Reagent (ThermoFisher Scientific, https:/ / www.thermofisher.com) and tested for Zika virus RNA by using reverse transcription PCR and Sanger sequencing using primers that amplify a 667-nt region of the envelope protein gene. 
Serum specimens were collected from 297 pigs (20 from Tzucacab, 73 from Valladolid, 74 from Xkalakdzonot, and 130 from Xmatkuil). Thirty-eight (12.8\%) pigs were positive for flavivirus-specific antibodies. Thirteen (4.8\%) pigs were seropositive for Zika virus, $1(0.3 \%)$ pig was seropositive for West Nile virus, and $24(8.1 \%)$ pigs had antibodies to an undetermined flavivirus. Zika virus PRNT $_{90}$ titers ranged from 40 to 320 (Table 1). Eleven pigs seropositive for Zika virus were from Xmatkuil, and 1 each was from Tzucacab and Valladolid.

The entomologic investigation yielded 1,870 mosquitoes of 8 species that were sorted into 190 pools. Of these, 381 mosquitoes were collected inside pigpens, and $>50 \%$ were engorged (Table 2). Mosquitoes were tested for Zika virus RNA by reverse transcription PCR, and resulting amplification products were analyzed by Sanger sequencing. Five pools, all of which contained $\geq 1$ engorged mosquito, were positive for Zika virus sequence, and all consisted of mosquitoes collected inside pigpens in Xmatkuil (Genbank accession nos. MT309004-309008). One pool each of the following mosquito species tested positive: Aedes aegypti, Ae. taeniorhynchus, Culex lactator, Cx. nigripalpus, and $C x$. thriambus. All sequences were identical and differed from the positive control, an isolate from the state of Chiapas, Mexico, in 2016 (Genbank accession no. KX446950.2) in 1 nucleotide position, a $\mathrm{C} \rightarrow \mathrm{T}$ substitution at genomic position 1893.

\section{Conclusions}

We detected Zika virus RNA sequence in Ae. aegypti, Ae. taeniorhynchus, Cx. lactator, Cx. nigripalpus, and $C x$. thriambus mosquitoes that were temporally and spatially associated with pigs seropositive for this virus. The role of Culex spp. mosquitoes in Zika virus transmission has been debated, but the consensus among the arbovirus community is that they are inefficient vectors $(5,6)$. Culex spp. mosquitoes and Zika virus were first linked after experimental infection studies demonstrated that the $C x$. quinquefasciatus mosquito is a competent vector of this virus (7). Many other studies have shown otherwise, including a study that demonstrated that $C x$. quinquefasciatus mosquitoes in the state of Jalisco, Mexico, were refractory to Zika virus $(5,6,8)$.

Vector competence experiments have also evaluated mosquitoes from $\geq 6$ other Culex spp., although $C x$. lactator, $C x$. nigripalpus, and $C x$. thriambus mosquitoes are not among them, and none were able to transmit Zika virus (9). We add to the small number of studies that have detected Zika virus nucleic acid in field-collected Culex spp. mosquitoes $(7,10)$, but we did not isolate virus or provide evidence of a disseminated infection. We cannot dismiss the possibility that the Zika virus RNA-positive Culex spp. mosquitoes had recently fed upon a viremic host but virus replication had not occurred within the mosquito. Therefore, the link between Culex spp. mosquitoes and Zika virus remains tenuous. The Ae. taeniorhynchus mosquito is also considered an inefficient vector of Zika virus (11). In contrast, the Ae. aegypti mosquito is the principal urban vector of Zika virus in the Americas (12). Ae. taeniorhynchus and Ae. aegypti mosquitoes are not known to have a strong preference for porcine blood, although $2.4 \%$ of engorged Ae. taeniorhynchus mosquitoes in the Galapagos Islands had acquired blood from pigs, and the $C x$. nigripalpus mosquito shifts seasonally to opportunistic feeding behavior $(13,14)$. Porcine blood has occasionally been detected in Ae. aegypti mosquitoes $(15,16)$.

\begin{tabular}{|c|c|c|c|c|c|c|c|c|c|c|}
\hline \multirow[b]{2}{*}{ Serum ID } & \multirow{2}{*}{$\begin{array}{c}\text { Sample } \\
\text { date† }\end{array}$} & \multirow{2}{*}{$\begin{array}{c}\text { Age } \\
\text { category }\end{array}$} & \multicolumn{8}{|c|}{ Virus and $\mathrm{PRNT}_{90}$ titer } \\
\hline & & & DENV-1 & DENV-2 & DENV-3 & DENV-4 & ILHV & SLEV & WNV & Zika virus \\
\hline XM-278-J‡ & $2018 \mathrm{Apr}$ & $\mathrm{J}$ & - & 20 & - & - & - & - & - & 320 \\
\hline XM-285-J & $2018 \mathrm{Apr}$ & $\mathrm{J}$ & - & 40 & - & 20 & - & - & - & 160 \\
\hline VA-265-A & 2018 Jun & A & - & - & - & - & - & - & - & 80 \\
\hline XM-O2A-J & 2018 Jun & J & - & 20 & 20 & - & 40 & 20 & 40 & 160 \\
\hline XM-177-J & 2018 Jun & $J$ & - & - & - & - & - & - & - & 40 \\
\hline XM-181-J & 2018 Jun & $\mathrm{J}$ & - & - & 20 & 20 & - & - & - & 80 \\
\hline XM-183-S & 2018 Jun & S & - & - & - & - & - & - & - & 40 \\
\hline XM-189-J & 2018 Jun & $\mathrm{J}$ & 80 & - & 20 & 20 & 40 & - & 40 & 320 \\
\hline XM-199-J & 2018 Jun & $J$ & - & - & - & - & - & - & - & 40 \\
\hline XM-202-J & 2018 Jun & $\mathrm{J}$ & - & 20 & 20 & - & - & - & - & 80 \\
\hline XM-212-J & 2018 Jun & $\mathrm{J}$ & - & - & - & - & - & - & _- & 80 \\
\hline XM-238-J & 2018 Jun & $\mathrm{J}$ & - & - & - & - & - & - & - & 40 \\
\hline TZ-387-J & 2019 Jan & $\mathrm{J}$ & - & - & - & - & - & - & - & 80 \\
\hline
\end{tabular}

${ }^{*} \mathrm{~A}$, adult; DENV1, dengue virus type 1; DENV2, dengue virus type 2; DENV3, dengue virus type 3; DENV4, dengue virus type 4; ILHV, Ilheus virus; J, juvenile; PRNT $90,>90 \%$ reduction in the number of plaques on plaque-reduction neutralization test; S, suckling; SLEV, St. Louis encephalitis virus; WNV, West Nile virus;,$- \leq 20$.

†Date (month/year) of serum collection.

$\ddagger$ Prefixes indicate pigs from these areas: TZ, Tzucacab; VA, Valladolid; XM, Xmatkuil. 
Table 2. Summary of mosquitoes collected inside pigpens, Yucatan, Mexico, 2018-2019

\begin{tabular}{|c|c|c|c|c|}
\hline Study site & Mosquito species & No. collected & No. pools & $\begin{array}{c}\text { No. pools positive for } \\
\text { Zika virus RNA }\end{array}$ \\
\hline \multirow[t]{4}{*}{ Tzucacab } & Aedes aegypti & 58 & 6 & 0 \\
\hline & Ae. taeniorhynchus & 3 & 1 & 0 \\
\hline & Culex quinquefasciatus & 63 & 7 & 0 \\
\hline & Cx. thriambus & 1 & 1 & 0 \\
\hline \multirow[t]{3}{*}{ Valladolid } & Ae. aegypti & 32 & 2 & 0 \\
\hline & Ae. cozumelensis & 1 & 1 & 0 \\
\hline & Cx. quinquefasciatus & 45 & 5 & 0 \\
\hline \multirow[t]{5}{*}{ Xkalakdzonot } & Ae. aegypti & 46 & 5 & 0 \\
\hline & Ae. cozumelensis & 2 & 1 & 0 \\
\hline & Anopheles albimanus & 6 & 1 & 0 \\
\hline & Cx. lactator & 1 & 1 & 0 \\
\hline & Cx. quinquefasciatus & 60 & 6 & 0 \\
\hline \multirow[t]{6}{*}{ Xmatkuil } & Ae. aegypti & 29 & 4 & 1 \\
\hline & Ae. taeniorhynchus & 8 & 2 & 1 \\
\hline & Cx. lactator & 1 & 1 & 1 \\
\hline & Culex nigripalpus & 3 & 1 & 1 \\
\hline & Culex quinquefasciatus & 21 & 2 & 0 \\
\hline & Culex thriambus & 1 & 1 & 1 \\
\hline
\end{tabular}

The mosquito infection rates in our study are high. All Zika virus RNA-positive mosquitoes and most seropositive pigs were sampled at the same site (Xmatkuil) on the same date (June 5, 2018). We speculate that these pigs were infected with Zika virus just before our visit and that some mosquitoes then bit them, without virus disseminating from the midguts of Culex spp. mosquitoes. Recent studies have demonstrated that pigs are susceptible to experimental Zika virus infection (1-4). We provide serologic evidence that pigs are also susceptible to natural Zika virus infection. A high number of stillbirths occurred at 2 study sites before sampling, but none displayed malformations typical of Zika virus infection.

We provide additional evidence that pigs produce neutralizing antibodies upon Zika virus exposure and are potential sentinels. This information will be useful for investigators and public and veterinary health personnel conducting surveillance in Zika virus-endemic areas where pigs are common and usually raised outdoors. One limitation of our study is that pig farmers were not tested for evidence of flavivirus infection. Future studies should investigate whether those persons are at increased risk for Zika disease.

\section{Acknowledgments}

We thank the Institutional Animal Care and Use Committee at the Universidad Autonoma de Yucatan for reviewing and approving this study.

This study was supported by Consejo Nacional de Ciencia y Tecnologia de Mexico grant no. PDCPN 2014-247005 (Problemas Nacionales) and in part by intramural funding provided by Iowa State University.

\section{About the Author}

Dr. Nunez-Avellaneda is a postdoctoral scientist in the College of Veterinary Medicine at Iowa State University. His research interests include studying the human and veterinary health impact and transmission dynamics of mosquito-transmitted viruses in Mexico.

\section{References}

1. Wichgers Schreur PJ, van Keulen L, Anjema D, Kant J, Kortekaas J. Microencephaly in fetal piglets following in utero inoculation of Zika virus. Emerg Microbes Infect. 2018;7:42. https://doi.org/10.1038/s41426-018-0044-y

2. Darbellay J, Cox B, Lai K, Delgado-Ortega M, Wheler C, Wilson $\mathrm{D}$, et al. Zika virus causes persistent infection in porcine conceptuses and may impair health in offspring. EBioMedicine. 2017;25:73-86. https:// doi.org/10.1016/ j.ebiom.2017.09.021

3. Darbellay J, Lai K, Babiuk S, Berhane Y, Ambagala A, Wheler C, et al. Neonatal pigs are susceptible to experimental Zika virus infection. Emerg Microbes Infect. 2017;6:e6. https://doi.org/10.1038/emi.2016.133

4. Ragan IK, Blizzard EL, Gordy P, Bowen RA. Investigating the potential role of North American animals as hosts for Zika virus. Vector Borne Zoonotic Dis. 2017;17:161-4. https://doi.org/10.1089/vbz.2016.2099

5. Roundy CM, Azar SR, Brault AC, Ebel GD, Failloux AB, Fernandez-Salas I, et al. Lack of evidence for Zika virus transmission by Culex mosquitoes. Emerg Microbes Infect. 2017;6:e90. https://doi.org/10.1038/emi.2017.85

6. van den Hurk AF, Hall-Mendelin S, Jansen CC, Higgs S. Zika virus and Culex quinquefasciatus mosquitoes: a tenuous link. Lancet Infect Dis. 2017;17:1014-6. https:/ / doi.org/10.1016/ S1473-3099(17)30518-2

7. Guedes DR, Paiva MH, Donato MM, Barbosa PP, Krokovsky L, Rocha SWDS, et al. Zika virus replication in the mosquito Culex quinquefasciatus in Brazil. Emerg Microbes Infect. 2017;6:e69. https://doi.org/10.1038/emi.2017.59

8. Elizondo-Quiroga D, Ramírez-Medina M, Gutiérrez-Ortega A, Elizondo-Quiroga A, Muñoz-Medina JE, Sánchez-Tejeda G, et al. Vector competence of Aedes aegypti and Culex quinquefasciatus from the metropolitan area of Guadalajara, 
Jalisco, Mexico for Zika virus. Sci Rep. 2019;9:16955 https:/ / doi.org/10.1038/s41598-019-53117-1

9. Epelboin Y, Talaga S, Epelboin L, Dusfour I. Zika virus: an updated review of competent or naturally infected mosquitoes. PLoS Negl Trop Dis. 2017;11:e0005933. https:/ / doi.org/10.1371/journal.pntd.0005933

10. Elizondo-Quiroga D, Medina-Sánchez A,

Sánchez-González JM, Eckert KA, Villalobos-Sánchez E, Navarro-Zúñiga AR, et al. Zika virus in salivary glands of five different species of wild-caught mosquitoes from Mexico. Sci Rep. 2018;8:809. https://doi.org/10.1038/ s41598-017-18682-3

11. Hart CE, Roundy CM, Azar SR, Huang JH, Yun R, Reynolds E, et al. Zika virus vector competency of mosquitoes, Gulf Coast, United States. Emerg Infect Dis. 2017;23:559-60. https://doi.org/10.3201/eid2303.161636

12. Kauffman EB, Kramer LD. Zika Virus mosquito vectors: competence, biology, and vector control. J Infect Dis. 2017;216(suppl_10):S976-90. https://doi.org/10.1093/ infdis/jix405

13. Edman JD, Taylor DJ. Culex nigripalpus: seasonal shift in the bird-mammal feeding ratio in a mosquito vector of human encephalitis. Science. 1968;161:67-8. https://doi.org/ 10.1126/science.161.3836.67
14. Bataille A, Fournié G, Cruz M, Cedeño V, Parker PG, Cunningham AA, et al. Host selection and parasite infection in Aedes taeniorhynchus, endemic disease vector in the Galápagos Islands. Infect Genet Evol. 2012;12:1831-41. https://doi.org/10.1016/j.meegid.2012.07.019

15. Olson MF, Ndeffo-Mbah ML, Juarez JG, Garcia-Luna S, Martin E, Borucki MK, et al. High rate of non-human feeding by Aedes aegypti reduces Zika virus

transmission in south Texas. Viruses. 2020;12:E453. https://doi.org/10.3390/v12040453

16. Sivan A, Shriram AN, Sunish IP, Vidhya PT. Host-feeding pattern of Aedes aegypti and Aedes albopictus (Diptera: Culicidae) in heterogeneous landscapes of South Andaman, Andaman and Nicobar Islands, India. Parasitol Res. 2015;114:3539-46. https://doi.org/10.1007/s00436-015-4634-5

Address for correspondence: Carlos Machain-Williams, Laboratorio de Arbovirologia, Centro de Investigaciones Regionales Dr. Hideyo Noguchi, Edificio Inalámbrica, Calle 43 No. 613 x Calle 90, Colonia Inalámbrica, Universidad Autónoma de Yucatán, Mérida, Yucatán CP 97000, Mexico; email: carlos.machain@correo.uady.mx

\section{EID Podcast}

\section{Community Interventions for Pregnant Women with Zika Virus in Puerto Rico}

\section{After experiencing an alarming rise in Zika virus infections, the Puerto Rico Department of Health partnered with CDC to implement a variety of community education and prevention efforts. But what were these efforts, and were they ultimately successful?}

In this EID podcast, Dr. Giulia Earle-Richardson, a behavioral scientist at $C D C$, analyzes some of the Zika intervention campaigns in Puerto Rico.

Visit our website to listen: https://go.usa.gov/xy6nD 